\title{
Influence of Oxidized Oils on Digestibility of Caseins in O/W Emulsions
}

\author{
Mónica Obando, Erika Soto, and Bruno De Meulenaer*
}

The impact of lipid oxidation on protein modifications in emulsions and the consequences on protein digestibility remains unclear. In this study, this impact is evaluated in casein $\left(6 \mathrm{mg} \mathrm{mL}^{-1}\right)$ based emulsions containing oxidized soybean or fish oil $(3 \%)$ in presence $(0.3 \%)$ or absence of the emulsifier Tween 20. Emulsions are prepared using oils at three oxidation levels and subsequently the impact on protein digestibility is evaluated after $24 \mathrm{~h}$ incubation at $4{ }^{\circ} \mathrm{C}$. Remarkably, protein digestibility increases in emulsions containing medium and highly oxidized fish oil: $70 \pm 0.4 \%$ and $73 \pm 0.4 \%$ of the proteins are digested, respectively, whereas protein digestibility in emulsions containing low oxidized fish oil amounted to $63 \pm 0.4 \%$. Protein digestibility in emulsions containing soybean oil stabilized by Tween 20 is not influenced by the oxidation level of the oil used. A remarkable tendency is observed for the malondialdehyde content of the emulsions depending on the presence of Tween 20. For soybean oil based emulsions, malondialdehyde concentrations are consistently higher in the presence of Tween 20. On the other hand, for the fish oil based emulsions an opposite trend is observed, except at the highest oxidation level evaluated, for which no significant differences can be detected. It is concluded that the composition of the interface in emulsions depends strongly upon the degree of oil oxidation and the presence of other emulsifiers. If the oil is more oxidized, less protein is present in the interface restricting the impact of lipid oxidation products on the proteins and hence their digestibility.

Practical Applications: This research was done to highlight the relevance of the interfacial composition in food emulsions and its influence on dairy protein digestibility. The food industry must be aware of the oil quality and the presence of emulsifiers in foods emulsions that allow to preserve the stability and nutritional characteristics of these food emulsions.

\section{Introduction}

Lipid oxidation causes degradation of foods, generating off-odors and off-flavors. A great proportion of foods are in the form of emulsions where proteins, such as milk proteins, play an important role as an emulsifier but also as a source of essential nutrients. In protein stabilized emulsions, lipid oxidation occurs simultaneously with protein oxidation, a phenomenon called by some authors "co-oxidation." ${ }^{[1-3]}$ Due to the interaction between proteins and the lipid oxidation process and the lipid oxidation products, these biopolymers are substantially modified. ${ }^{[4-6]}$ The interfacial area is a critical area in emulsions with regard to the development of lipid oxidation because it is the contact area between the lipid and the aqueous phase, hence the emulsifier (type and concentration) can greatly influence the oxidation..$^{[7]}$ Dairy proteins are mostly used such as emulsifiers, but the impact of lipid-protein co-oxidation on protein digestibility has been scarcely studied. Recently some authors tried to elucidate the impact of lipid oxidation products on protein digestibility, protein modifications, and even, toxicological consequences in vivo. $^{[3,8-9]}$ In our previous research, ${ }^{[3]}$ protein stabilized emulsions, proteins and lipids were subjected to a simultaneous oxidation process, via respectively autoxidation and photo-oxidation mechanisms. For both mechanism protein digestibility

Dr. M. Obando, Dr. B. De Meulenaer

NutriFOODchem Unit

Department of Food Safety and Food Quality (Partner in Food2Know)

Faculty of Bioscience Engineering

Ghent University

Coupure Links 653, B-9000 Ghent, Belgium

E-mail: Bruno.DeMeulenaer@UGent.be

M. Obando, E. Soto

Agroindustrial Engineering

Department of Sanitation and Vegetable Production

Faculty of Agronomic Engineering

Universidad del Tolima

Santa Helena, 564 Ibagué, Colombia

The ORCID identification number(s) for the author(s) of this article can be found under https://doi.org/10.1002/ejlt.201700331.

DOI: 10.1002/ejlt.201700331 was considerably affected. Due to the particular experimental setup chosen it could not be evaluated if the effects were primarily due to the reaction of the generated lipid oxidation products with proteins or if also the potential concomitant protein oxidation was necessary. Therefore the aim of the current study was to evaluate the impact of the reactions occurring between lipid oxidation products and proteins in emulsions on the protein digestibility. In that way it was intended to prioritize the effects of lipid oxidation products over potential concomitant protein oxidation using short time incubation at low temperature $\left(4^{\circ} \mathrm{C}, 24 \mathrm{~h}\right)$. Therefore, oxidized fish or soybean oil with different oxidation levels were used to prepare casein based emulsions in presence or absence of Tween 20 to modify the interface. Casein was used in this experiment based on the results of the previous research, in which was shown that casein 
proteins were more susceptible to changes in digestibility upon their interaction with oxidizing lipids, as compared to whey proteins.

\section{Experimental Section}

\subsection{Materials}

Sodium caseinate was provided by Arla Foods (Wageningen, Netherlands). Food grade soybean oil was purchased from a local store and fish oil was provided by Smit \& Zoon (Weesp, Netherlands). Chemicals of analytical grade were obtained from Sigma-Aldrich (Bornem, Belgium), VWR (Leuven, Belgium), Merck (Darmstadt, Germany) and Acros Organics (Geel, Belgium). Gel and standards for SDS-PAGE were from BioRad (Nazareth, Belgium). Potassium phosphate buffer $0.1 \mathrm{M} \mathrm{pH}$ 7.4 , consisted of $\mathrm{K}_{2} \mathrm{HPO}_{4}$ and $\mathrm{KH}_{2} \mathrm{PO}_{4}$. Polyethylene glycol sorbitan monolaurate (Tween 20) from Sigma-Aldrich was used as surfactant.

\subsection{Oil Stripping}

The stripping of the oil was carried out following the procedure outlied by Mariod et al., ${ }^{[10]}$ with modifications. First, oils were purified by passing $50 \mathrm{~g}$ of oil was added to $50 \mathrm{~mL}$ of hexane through a chromatographic glass column $(20 \mathrm{~mm}$ internal diameter) filled with $25 \mathrm{~g}$ of silica gel $60(0.0063-0.100 \mathrm{~mm}$, Merck) and hexane. The column was wrapped with aluminum foil to prevent light-induced oxidation during the process and the oil was also collected in an aluminum foil-wrapped flask. The column was rinsed three times with $50 \mathrm{~mL}$ of hexane and the mix of oil and solvent was collected and rota-evaporated at $35^{\circ} \mathrm{C}$ using a vacuum. The solvent traces were removed by flushing with nitrogen. Subsequently the oil was mixed with $56 \mathrm{~mL}$ petroleum ether which was passed through a second glass column filled with $100 \mathrm{~g}$ of activated aluminum oxide (activated basic, 199443 Sigma-Aldrich) and petroleum ether. The column was also wrapped with aluminum foil and finally, rinsed with $100 \mathrm{~mL}$ of hexane and collected in an aluminum foil-wrapped flask. The solvent in the eluent was rota-evaporated at $35^{\circ} \mathrm{C}$ using a vacuum and the solvent traces were removed by flushing with nitrogen. The samples were kept in brown glass bottles with a minimum headspace which was flushed under nitrogen and stored at $-80^{\circ} \mathrm{C}$ until emulsion preparation.

\subsection{Oxidation of the Oils Used in the Emulsions}

Fish and soybean stripped oil subsamples of $70 \mathrm{~g}$ were oxidized in an open petri dish using an oven at $60^{\circ} \mathrm{C}$ for 2 and $4 \mathrm{~h}$, respectively. These oils were considered to have a high oxidation level. Medium oxidized oils were obtained by mixing these oils with the original non-oxidized stripped oils in a 1:1 ratio. The oxidation status of the oils was determined by spectrophotometric determination of the peroxide value $(\mathrm{POV})^{[11]}$ and $\mathrm{p}$-anisidine value $(\mathrm{p}-\mathrm{AV})^{[12]}$ as a measure for the concentration of respectively the primary and secondary oxidation products.

\subsection{Emulsion Preparation and Storage Conditions}

Emulsions were prepared using fish and soybean oil, respectively (using three levels of oxidation status for each oil as described), in presence or absence of Tween 20 (0.3\%).

Oil-in-water emulsions were prepared in $0.1 \mathrm{M}$ potassium phosphate buffer pH 7.4 containing $30 \mathrm{mg} \mathrm{mL}^{-1}$ (3\%) of soybean or fish stripped oil, respectively, with $6 \mathrm{mg} \mathrm{mL}^{-1}$ of sodium caseinate. The protein isolate was dissolved and mixed with $0.1 \mathrm{M}$ potassium phosphate buffer $\mathrm{pH} 7.4$ for $1 \mathrm{~h}$ at room temperature. In case of emulsions with only protein, the stripped oil was added to the protein solution $\left(60^{\circ} \mathrm{C}\right)$ and mixed with a high speed blender (Janke and Kunkel, IKA-Werk, Staufeb, Germany) for $2 \mathrm{~min}$ at $11000 \mathrm{rpm}$ to have a pre-emulsion. For emulsions with the additional surfactant, a pre-emulsion with Tween 20, stripped oil and $0.1 \mathrm{M}$ potassium phosphate buffer was made using the sonicator for $15 \mathrm{~min}$. After that, the protein previously dissolved with $0.1 \mathrm{~m}$ potassium phosphate buffer was added. All pre-emulsions were heated at $60^{\circ} \mathrm{C}$ and blended with a high speed blender (Janke and Kunkel, IKA-Werk, Staufeb) for $2 \mathrm{~min}$ at $11000 \mathrm{rpm}$. Then, all pre-emulsions were homogenized at 250 bar (first stage) and 50 bar (second stage) by high pressure homogenizer APV Lab 1000 (APV Benelux NV/SA, Erpe Mere, Belgium) for five passes. Duran bottles of $250 \mathrm{~mL}$ were filled with $100 \mathrm{~mL}$ of emulsion, then, samples were cooled fast and incubated at $4{ }^{\circ} \mathrm{C}$ for $24 \mathrm{~h}$. All samples were prepared in triplicate.

\subsection{Lipid Characterisation}

The lipids were characterized by their fatty acid profile. After saponification of triacylglycerols with a methanolic $\mathrm{NaOH}$ solution, the fatty acids were esterified with $\mathrm{BF} 3 / \mathrm{MeOH}$ reagent in presence of $\mathrm{NaOH}$. The methyl esters were injected cold oncolumn in a gas chromatograph $(6890 \mathrm{~N}$, Agilent Technologies, Diegem, Belgium) equipped with a capillary column CP-Sil 88 for FAME $(60 \mathrm{~m} \times 0.25 \mathrm{~mm}$ ID $\times 0.20 \mu \mathrm{m}$ film thickness $)$ from Varian (Sint-Katelijne-Waver, Belgium) and a flame ionization detector operated at $300^{\circ} \mathrm{C}$. The oven was programmed as follows: $50^{\circ} \mathrm{C}$ for $4 \mathrm{~min}$, increasing to $120^{\circ} \mathrm{C}\left(10^{\circ} \mathrm{C} \mathrm{min}^{-1}\right)$ and further to $163^{\circ} \mathrm{C}\left(5^{\circ} \mathrm{C} \mathrm{min}^{-1}\right)$ and holding at $163^{\circ} \mathrm{C}$ for $19 \mathrm{~min}$. Finally the temperature was increased to $225^{\circ} \mathrm{C}\left(10^{\circ} \mathrm{C} \mathrm{min}^{-1}\right)$ and held for $16 \mathrm{~min}$. Helium was used as carrier $\left(1 \mathrm{~mL} \mathrm{~min}^{-1}\right)$ and make up gas $\left(20 \mathrm{~mL} \mathrm{~min}^{-1}\right)$. Nonadecanoid acid was added as an internal standard. ${ }^{[13]}$

\subsection{Malondialdehyde (MDA) Determination}

Malondialdehyde determination was performed following the method described earlier by Papastergiadis et al. ${ }^{[14]}$ Trichloroacetic acid was added to the samples until a final concentration of $15 \%$ to precipitate the proteins. Samples were then centrifuged at $13000 \times \mathrm{g}$ to get a clear supernatant. The top layer was discarded and $1 \mathrm{~mL}$ of supernatant was mixed with $3 \mathrm{~mL}$ of TBA reagent ( $40 \mathrm{~mm}$ dissolved in $2 \mathrm{M}$ acetate buffer at $\mathrm{pH} 2.0$ ) in a test tube and heated in a boiling water bath for $40 \mathrm{~min}$. The reaction mixture was cooled prior to the addition of $1 \mathrm{~mL}$ of methanol, 
and $20 \mu \mathrm{L}$ of the sample was injected into a Varian C18 HPLC column $(5 \mu \mathrm{m}, 150 \times 4.6 \mathrm{~mm})$, held at $30^{\circ} \mathrm{C}$ using an Agilent 1100 HPLC system (Agilent Technologies, Boblingen, Germany). The mobile phase consisted of $50 \mathrm{~mm} \mathrm{KH}_{2} \mathrm{PO}_{4}$ buffer solution, methanol, and acetonitrile (72:17:11, v/v/v, pH $5.3)$, pumped isocratically at $1 \mathrm{~mL} \mathrm{~min}^{-1}$. Fluorometric detector excitation and emission wavelengths were set at 525 and $560 \mathrm{~nm}$, respectively. For quantification, standard solutions of MDA in 7.5\% TCA were prepared from 1,1,3,3-tetraethoxypropane (TEP) and calibration curves were prepared at a concentration ranging from 0.6 to $10 \mu \mathrm{M}$.

\subsection{Hexanal Determination}

Hexanal formation in emulsions was evaluated using headspace solid-phase microextraction (HS-SPME) combined with gas chromatography-mass spectrometry (GC-MS). A total of $1 \mathrm{~mL}$ of emulsion was placed in a glass headspace vial (size $10 \mathrm{~mL}$ ) and mixed with $2 \mathrm{~mL}$ of $0.02 \mathrm{M}$ buffer prepared with $\mathrm{Na}_{2} \mathrm{HPO}_{4}$ and $\mathrm{KH}_{2} \mathrm{PO}_{4}$, pH 2.0 (adjusted with phosphoric acid). Butylated hydroxyanisol (BHA) dissolved in methanol was added in the vial at a final concentration of $2.8 \mathrm{M}$ and a known amount of hexanal-d12 in methanol was incorporated in the sample. The vial was sealed with a PTFE septum cup and was subjected to HS- SPME extraction. The SPME fiber ( $75 \mu \mathrm{m}$ Carboxen/PDMS, Supelco, Bellefonte, PA) was inserted into the headspace of the vial and left there for $30 \mathrm{~min}$ at $75^{\circ} \mathrm{C}$. Volatile compounds were desorbed by inserting the fiber into the injection port of an Agilent 7890A chromatograph (Agilent Technologies, Palo Alto, CA) operated in splitless mode for $10 \mathrm{~min}$ at $240^{\circ} \mathrm{C}$. Helium was used as carrier gas with a constant flow rate of $1.3 \mathrm{~mL} \mathrm{~min}^{-1}$. The compounds were separated on a DB-624 column $(60 \mathrm{~m} \times 0.25 \mathrm{~mm} \times 1.4 \mathrm{~mm})$. The oven temperature program began at $50^{\circ} \mathrm{C}$ for $5 \mathrm{~min}$, followed by an increase to $4^{\circ} \mathrm{C} \mathrm{min}^{-1}$ to $140^{\circ} \mathrm{C}$, then $30^{\circ} \mathrm{C} \mathrm{min}^{-1}$ to $240^{\circ} \mathrm{C}$ for $10 \mathrm{~min}$. An Agilent 5975C inert XL mass spectrometry detector was used and detection was carried out on the total ion current obtained by electron impact at $70 \mathrm{eV}$. An external calibration curve was prepared. The selected ions for quantification were 64 and 56 for hexanal-d12 and hexanal, respectively.

\subsection{Protein-Bound Carbonyls}

Protein carbonyls were determined after derivatisation with 2,4dinitrophenylhydrazine (DNPH). ${ }^{[15]}$ Therefore, $0.4 \mathrm{~mL}$ DNPH $(10 \mathrm{~mm}$ in $2 \mathrm{M} \mathrm{HCl})$ was added to $0.3 \mathrm{~mL}$ of emulsion and subsequently incubated in the dark for $60 \mathrm{~min}$ at room temperature with constant stirring. Afterwards $0.7 \mathrm{~mL}$ trichloroacetic acid (TCA) was added ( $10 \% \mathrm{~m} / \mathrm{v}$ final concentration) and the samples were incubated on ice during $10 \mathrm{~min}$ and centrifuged $(9000 \times \mathrm{g})$ for $3 \mathrm{~min}$ at $20^{\circ} \mathrm{C}$. The protein pellets were washed three times with $1 \mathrm{~mL}$ ethanol:ethylacetate $(1: 1, \mathrm{v} / \mathrm{v})$ to remove the excess DNPH. The final pellet was re-dissolved in $0.5 \mathrm{~mL} 6 \mathrm{~m}$ urea in $20 \mathrm{~mm}$ potassium phosphate buffer $(\mathrm{pH} 2.3)$ and the absorbance was measured at $370 \mathrm{~nm}$ using Bio-Rad Benchmark Plus microplate spectrophotometer (Nazareth, Belgium). The protein-bound carbonyl content was calculated using a molar absorption coefficient of $22000 \mathrm{M}^{-1} \mathrm{~cm}^{-1}$.

\subsection{Tryptophan, N-Formylkynurenine (NFK), and Lipid-Protein Adducts}

The tryptophan, NFK content, and lipid-protein adducts were measured fluorometrically (Spectramax Gemini XPS fluorimeter, Molecular Devices, Brussels, Belgium) on the emulsions. For this, $50 \mu \mathrm{L}$ of emulsion was diluted in $250 \mu \mathrm{L} 6 \mathrm{M}$ urea in PBS buffer ( $\mathrm{pH} 7.4$ ) to completely unfold the protein structure. For tryptophan excitation and emission wavelengths were 280 and $330 \mathrm{~nm}$. For NFK, 330 and $440 \mathrm{~nm}$ were used and for lipidprotein adducts $350 \mathrm{~nm}$ and $440 \mathrm{~nm}$ were applied. ${ }^{[16]}$

\subsection{Available Lysine Determination}

The loss of reactive lysine was monitored using derivatisation with ortho-phthaldialdehyde (OPA) in the presence of 2 mercaptoethanol which yielded a fluorescent product which was measured at $340 \mathrm{~nm}$ (excitation) and $450 \mathrm{~nm}$ (emission). ${ }^{[17]}$ Samples $(50 \mu \mathrm{L})$ containing $6 \mathrm{mg} \mathrm{mL}^{-1}$ protein were incubated with sodium dodecyl sulphate (SDS) $12 \%(50 \mu \mathrm{L})$ overnight at $4{ }^{\circ} \mathrm{C}$. After sonication for $15 \mathrm{~min}$ at $30^{\circ} \mathrm{C}, 750 \mu \mathrm{L}$ of OPA was mixed with $25 \mu \mathrm{L}$ of sample, vortexed, and incubated for $2 \mathrm{~min}$ and the relative fluorescence intensity was measured. $\beta$-casein was used to prepare a calibration curve.

\subsection{Electrophoresis}

Sodium dodecyl sulfate polyacrylamide gel electrophoresis (SDS-PAGE) was carried out by, mixing $10 \mu \mathrm{L}$ of diluted sample $\left(1 \mathrm{mg}\right.$ protein $\mathrm{mL}^{-1}$ ) with $10 \mu \mathrm{L}$ of Laemmli buffer (Bio-Rad, Nazareth, Belgium) containing 0.05\% mercaptoethanol. Samples were heated for $5 \mathrm{~min}$ at $90^{\circ} \mathrm{C}$ and centrifuged for $5 \mathrm{~min}$ at $13200 \mathrm{~g}$. Subsequently, $10 \mu \mathrm{L}$ of solution was brought onto a $15 \%$ polyacrylamide Tris-HCl gel (Bio-Rad). Electrophoresis was performed at a constant voltage of $160 \mathrm{~V}$. The gels were stained with Biosafe Coomassie (Bio-Rad), and a precision plus protein standard (Bio-Rad) was used as a molecular weight marker.

\subsection{In Vitro Model Digestion}

A static in vitro model digestion was applied for emulsions, considering the oral phase as negligible due to fast swallowing. For the gastric phase the $\mathrm{pH}$ of each sample $(5 \mathrm{~mL})$ was adjusted to 2.0 with $8 \mathrm{M} \mathrm{HCl}$. Pepsin (P6867 Sigma-Aldrich) was added at an enzyme/protein ratio of $1 / 250(\mathrm{w} / \mathrm{w})$ in a solution of $10 \mathrm{mg}$ in $1 \mathrm{~mL}$ water. Samples were incubated at $37^{\circ} \mathrm{C}$ for $2 \mathrm{~h}$ with constant shaking. After this, the duodenal phase was initiated by increasing the $\mathrm{pH}$ to 6.5 with $\mathrm{NaOH} 8 \mathrm{M}$. Lipase $(100-400$ units $\mathrm{mg}^{-1} \mathrm{~L} 3126$ Sigma-Aldrich) $1.6 \mathrm{mg} \mathrm{mL}^{-1}$ and $5 \mathrm{mg} \mathrm{mL}^{-1}$ of bile salts (B8631 Sigma-Aldrich) were diluted in $5 \mathrm{~mm}$ phosphate buffer with $1.7 \mathrm{mg} \mathrm{mL}^{-1} \mathrm{CaCl}_{2}$ and $400 \mu \mathrm{L}$ were added to the sample. Trypsin (T0303 Sigma-Aldrich) at an enzyme/protein ratio $1 / 250(\mathrm{w} / \mathrm{w})$ and $\alpha$-chymotrypsin (C4129 Sigma-Aldrich) at an enzyme/protein ratio $1 / 250(\mathrm{w} / \mathrm{w})$ were added using a solution of $10 \mathrm{mg}$ in $1 \mathrm{~mL} 0.1 \mathrm{M} \mathrm{HCl}$ to each sample. Incubation at $37^{\circ} \mathrm{C}$ for $2.5 \mathrm{~h}$ was done with constant 
shaking. At the end of the incubation, the $\mathrm{pH}$ was adjusted to 5.0 with $8 \mathrm{M} \mathrm{HCl}$ to stop the digestion.

\subsection{Digestibility}

Protein extraction with $30 \%$ TCA (w/v) was done to get a $15 \%$ TCA final concentration in each sample. Samples were kept on ice during $10 \mathrm{~min}$ to ensure total precipitation of undigested proteins. Centrifugation at $13000 \times \mathrm{g}$ for $10 \mathrm{~min}$ was done and the supernatant was discarded. The pellet was re-dissolved in $10 \% \mathrm{NaOH}$ and the nitrogen content was determined by the Kjeldahl method. Digestibility was calculated as follows:

$\%$ Digestibility $=(1-\mathrm{N}(\mathrm{mg})$ digested samples $/ \mathrm{N}(\mathrm{mg})$ non digested samples $) \times 100$

\subsection{Statistical Analysis}

Three-way ANOVA test for statistical comparison among the results was done, applying a sig-nificance level of $p<0.05$ (Tukey test). One-way ANOVA was used to compare the treatments over the oxidation level, using a significance level of $p<0.05$. Oneway ANOVA was also applied to compare emulsions with and without Tween 20 or emulsions with soybean oil versus fish oil. Normality was checked with a Kolmogorov-Smirnov test and a Levene test has applied to confirm the homogeneity of variances. The SPSS 22 statistics package was used.

\section{Results}

From the statistics, it can be concluded that the studied variables were significantly influenced by almost all factors considered and by the interactions among them. Since this research aimed to evaluate how protein digestibility has impacted emulsions, as influenced by the degree of oxidation of emulsified oils, the reported data were evaluated using a one-way ANOVA considering the degree of oxidation as a factor. The interactions among the factors were considered significant with respect to the interpretation of the data observed.

Soybean and fish oils were characterized by their fatty acid profile (Table 1), purified by removing their minor compounds (i.e., phenolic compounds, tocopherols, and phytosterols), and then subjected to accelerated auto-oxidation at $60^{\circ} \mathrm{C}$. The oxidation levels of the oils, which were selected by measuring the peroxide and $p$-anisidine values, were characterized by lipid oxidation products (i.e., malondialdehyde and hexanal; Table 2). These oils (3\% concentration) were used to prepare casein-based emulsions that were either stabilized by the addition of Tween 20 (0.3\% concentration) or left without adding Tween 20 . The malondialdehyde and hexanal levels of these emulsions, measured after $24 \mathrm{~h}$ of incubation at $4{ }^{\circ} \mathrm{C}$, are shown in Table 3. For emulsions containing low-oxidized soybean oil, malondialdehyde was not detected.

Malondialdehyde levels in emulsions increased upon the progressive oxidation status of the oil used. Malondialdehyde
Table 1. Fatty acid profile of fish and soybean oils.

\begin{tabular}{lcc}
\hline & \multicolumn{2}{c}{ g fatty acid/100g fatty acids } \\
\cline { 2 - 4 } Fatty acid & Fish oil & Soybean oil \\
\hline C14:0 & 7.1 & 0.1 \\
C16:0 & 15.0 & 10.6 \\
C16:1 & 8.5 & 0.1 \\
C18:0 & 2.9 & 3.9 \\
C18:1c9 & 12.8 & 23.4 \\
C18:1c11 & 3.3 & 1.7 \\
C18:2 & 5.7 & 51.6 \\
C18:3n-3 & 1.3 & 6.4 \\
C18:3n-6 & 0.4 & 0.3 \\
C18:4 & 2.8 & 0.1 \\
C20:0 & 0.2 & 0.5 \\
C20:1 & 1.1 & 0.5 \\
C20:2 & 0.3 & - \\
C20:4 & 1.0 & - \\
C20:5 EPA & 18.4 & - \\
C22:0 & 0.1 & 0.4 \\
C22:1 & 0.6 & - \\
C22:4 & 0.8 & - \\
C22:6 DHA & 7.9 & - \\
\hline
\end{tabular}

was detected in emulsions containing low-oxidized fish oil, and its levels increased in parallel with the oxidation levels of this oil. For all emulsions containing low-oxidized soybean or fish oil, hexanal was detected below the limit of quantification $(77 \mathrm{ng}$ $\mathrm{mL}^{-1}$ ). For soybean oil-based emulsions, the amount of hexanal increased with the oil oxidation level. In soybean oil-based emulsions without Tween 20, the amount of carbonyls increased with greater oil oxidation levels (Figure 1). In the case of emulsions containing soybean or fish oil stabilized by Tween 20 , the level of carbonyls increased at medium oil oxidation level but did not increase any further in emulsions formulated with the most oxidized oils. In the absence of Tween 20 , the protein carbonyl content was remarkably higher $\left(4.0 \pm 0.4 \mu \mathrm{gg}^{-1}\right.$ protein) in emulsions containing fish oil compared to emulsions containing soybean oil $\left(2.1 \pm 0.1 \mu \mathrm{g} \mathrm{g}^{-1}\right.$ protein). In general, the samples containing oxidized oils stabilized by Tween 20 had a lower carbonyl content for all samples studied.

Protein-lipid adducts, as assessed by their fluorescence (Figure 2), increased with the oil oxidation level in soybean oil-based emulsion. In emulsions containing soybean oil stabilized by Tween 20, protein-lipid adducts increased at a medium oil oxidation level but did not increase any further in the emulsions formulated with the most oxidized oils. In fish oilbased emulsions at medium and high oil oxidation levels that were stabilized by Tween 20, protein-lipid adducts were significantly lower (305 and 342, respectively) than in emulsions containing fish oil in absence of Tween 20 (379 and 389, respectively). Protein-lipid adducts were higher in emulsions containing fish oil than in those containing soybean oil. 
Table 2. Characterisation of stripped oils at three oxidation levels.

\begin{tabular}{|c|c|c|c|c|c|}
\hline Oil & Oxidation levels & POV [meq O2 kg Oil] & p-AV [-] & Malondialdehyde $\left[\mathrm{ng} \mathrm{g}^{-1}\right]$ & Hexanal $\left[\mathrm{ng} \mathrm{g}^{-1}\right]$ \\
\hline \multirow[t]{3}{*}{ Soybean } & Low & $0.5 \pm 0.0$ & $1.1 \pm 0.3$ & $<\mathrm{LOD}$ & $164 \pm 8$ \\
\hline & Medium & $7.8 \pm 0.4$ & $4.0 \pm 0.1$ & $631 \pm 37$ & $2860 \pm 280$ \\
\hline & High & $15.5 \pm 1.5$ & $10.1 \pm 0.3$ & $1373 \pm 57$ & $8903 \pm 588$ \\
\hline \multirow[t]{3}{*}{ Fish } & Low & $2.9 \pm 0.1$ & $1.7 \pm 0.4$ & $2360 \pm 200$ & $164 \pm 10$ \\
\hline & Medium & $17.4 \pm 0.3$ & $5.2 \pm 0.4$ & $5576 \pm 54$ & $330 \pm 20$ \\
\hline & High & $28.9 \pm 1.0$ & $7.4 \pm 0.3$ & $9254 \pm 90$ & $521 \pm 30$ \\
\hline
\end{tabular}

Data are presented as mean of triplicates \pm standard deviation. $\mathrm{LOD}=0.03 \mu \mathrm{g} \mathrm{MDA} \mathrm{mL}^{-1}$.

Other amino acid modification markers, such as tryptophan, $\mathrm{N}$-formylkynurenine (NFK), and available lysine, are shown in Table 4. In all emulsions studied, the tryptophan content decreased when the oil oxidation level increased. In all soybean oil-based emulsions, NFK levels increased at medium oil oxidation but decreased again at a high oil oxidation. In fish oil-based emulsions, the NFK content increased and remained stable at a high oil oxidation, while in emulsions containing fish oil stabilized by Tween 20, NFK further increased at a high oil oxidation level.

As for the lysine available, a decrease was only observed at a high oil oxidation level in both types of soybean-based emulsions. In both types of fish oil emulsions, the lysine content decreased at a medium oil oxidation level; however, the amount of lysine available returned to its initial value at a high level of oil oxidation.

Protein digestibility was calculated by determining the nonprotein to total nitrogen ratio after digestion, and it was also monitored using electrophoresis (SDS-PAGE). Protein digestibility of the basic control (casein solution, $73.59 \pm 0.44 \%$ ) and emulsions containing low- and medium-oxidized soybean oil was $69.4 \%$ and $68.2 \%$, respectively, and it increased significantly (to $72.4 \%$ ) at a high oil oxidation level (Figure 3). Figure 4 shows the electrophoretic pattern of the control (casein solution) compared to the emulsions before and after digestion. In casein solution after digestion (lane 3) can be observed a complete digestion of the original proteins, even without bands at $10 \mathrm{KDa}$ or bands in the stacking gel, in contrast to the emulsions containing oxidized oil after digetion (lanes 5, 7, and 9) in which bands remains at 250
KDa. In emulsions containing soybean oil stabilized by Tween 20 , protein digestibility was not influenced by the oxidation level of the oil. In the case of fish oil-based emulsions, the lowest digestibility rate $(63 \%)$ was determined to exist in emulsions containing lowoxidized fish oil, and digestibility increased in parallel with the oil oxidation level. For emulsions containing fish oil stabilized by Tween 20, protein digestibility increased with a medium level of oil oxidation, but it did not increase any further in emulsions formulated with the most oxidized oils.

Figures 4 and 5 show the electrophoretic patterns of emulsions containing soybean or fish oils that were stabilized by or without Tween 20. As shown in Figure 4A, big aggregates (lane 6) were present in emulsions containing high-oxidized soybean oil before digestion, but these aggregates disappeared after digestion (lane 7). In Figure 4B, similar electrophoretic patterns are shown for various levels of oil oxidation in emulsions containing soybean oil stabilized by Tween 20. In Figures $5 \mathrm{~A}$ and $5 \mathrm{~B}$, aggregates $\mathrm{O}$ can be observed for emulsions containing low-oxidized fish oil (lane 3 ) after gastrointestinal digestion. The intensity of peptides between 6 and $10 \mathrm{kDa}$ was higher in emulsions stabilized by Tween 20 .

\section{Discussion}

Lipid oxidation generally occurs simultaneously with protein oxidation in complex matrices. In previous research, we reported the impact of the co-oxidation of lipids and proteins on reduced protein digestibility in oil-in-water emulsions subjected to auto-

Table 3. Lipid oxidation parameters (Malondialdehyde and hexanal) in casein based emulsions containing stripped soybean oil or stripped fish oil at three levels of oxidation, stabilized or not by Tween 20 (After $24 \mathrm{~h}$ incubation at $4{ }^{\circ} \mathrm{C}$ ).

\begin{tabular}{|c|c|c|c|c|c|c|}
\hline \multirow[b]{2}{*}{ Emulsions } & \multicolumn{3}{|c|}{ Malondialdehyde $\left(\mathrm{ng} \mathrm{mL}^{-1}\right.$ ) } & \multicolumn{3}{|c|}{ Hexanal $\left(\mathrm{ng} \mathrm{mL}^{-1}\right)$} \\
\hline & Low & Medium & High & Low & Medium & High \\
\hline Casein soybean oil emulsion & $<\operatorname{LOD}^{\mathrm{a}}$ & $65 \pm 2.5^{\mathrm{b}}$ & $106 \pm 0.0^{c}$ & $40 \pm 2.0^{\mathrm{a}, *}$ & $148 \pm 1.2^{b}$ & $481 \pm 3.8^{c}$ \\
\hline Casein soybean oil and Tween 20 & $<\operatorname{LOD}^{\mathrm{a}}$ & $95 \pm 0.0^{b}$ & $232 \pm 16^{c}$ & $41 \pm 0.8^{\mathrm{a}, *}$ & $137 \pm 2.0^{b}$ & $438 \pm 5.5^{c}$ \\
\hline Casein fish oil & $178 \pm 28^{\mathrm{a}}$ & $446 \pm 28^{b}$ & $576 \pm 19^{c}$ & $55 \pm 2.1^{\mathrm{a}, *}$ & $55 \pm 1.8^{\mathrm{a},{ }^{*}}$ & $78 \pm 0.9^{b}$ \\
\hline Casein fish oil and Tween 20 & $144 \pm 12^{a}$ & $320 \pm 7.4^{\mathrm{b}}$ & $558 \pm 45^{c}$ & $58 \pm 0.2^{\mathrm{a}, *}$ & $49 \pm 0.3^{b, *}$ & $70 \pm 1.8^{c, *}$ \\
\hline
\end{tabular}

Experimental data are presented as means of three independent replicates \pm standard deviation. Means with different superscript letters are significantly different $(p<0.05)$

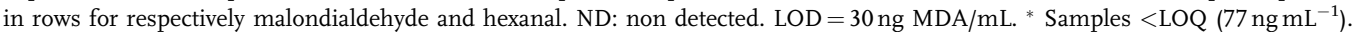




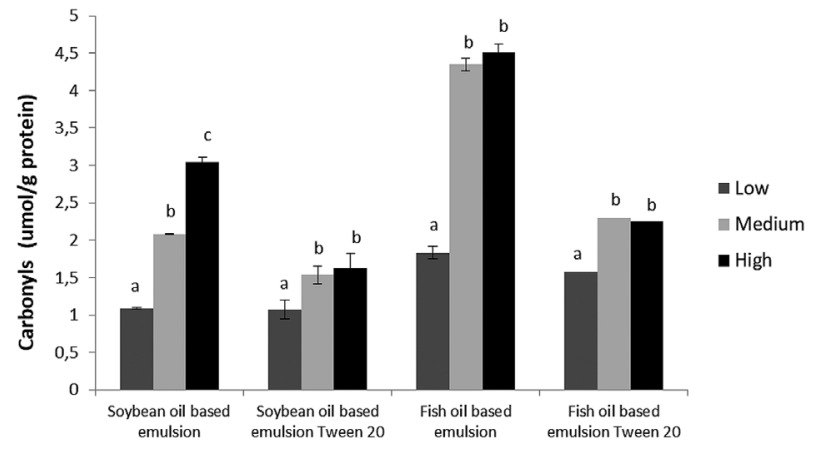

Figure 1. Carbonyls in casein based emulsions containing stripped soybean oil or stripped fish oil at three levels of oxidation, stabilized or not by Tween 20 (After incubation $24 \mathrm{~h}$ at $4^{\circ} \mathrm{C}$ ).

and photo-oxidation processes, respectively. ${ }^{[3]}$ From this previous study, it could not be concluded whether the co-oxidation process itself, or the interactions of the generated lipid oxidation products with proteins, or both phenomena were responsible for the observed impact on protein digestibility. Therefore, in this current study, we aimed at maximizing the latter interactions between lipid oxidation products and proteins by emulsifying oils with varying levels of oxidation with protein solutions. Comparing the secondary oxidation products (malondialdehyde and hexanal) in oils and emulsions (Tables 2 and 3), an increase in the levels of these products (in oil bases) was observed upon making the emulsions. Therefore, although reactions between those selected lipid oxidation products and proteins are likely to have occurred, an overall increase in their concentration was observed due to further lipid oxidation.

Consequently, it cannot be ruled out that, in parallel, this lipid oxidation may have induced protein oxidation even though it was intended to be minimized using the chosen experimental set up. Moreover, the impact of specific lipid oxidation products on proteins has already been described. ${ }^{[18]}$

Despite the fact that protein co-oxidation could not be excluded from the experimental set up, it is obvious that reactions between lipid oxidation products and proteins have occurred, as intended. Comparing the malondialdehyde and hexanal levels in the emulsion $\left(0.06-0.57 \mu \mathrm{g} \mathrm{mL}^{-1}\right.$ and $0.08-$ $0.48 \mu \mathrm{g} \mathrm{mL}^{-1}$, respectively) with those observed in previous research, ${ }^{[3]}$ in which casein emulsions were subjected to auto-

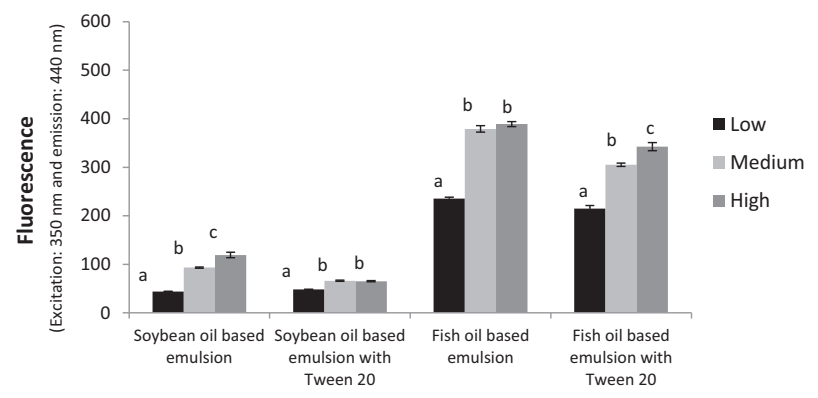

Figure 2. Protein-lipid adducts in casein based emulsions containing stripped soybean oil or stripped fish oil at three levels of oxidation, stabilized or not by Tween 20 (After incubation $24 \mathrm{~h}$ at $4{ }^{\circ} \mathrm{C}$ ). and photo-oxidation $\left(0.05-2.1 \mu \mathrm{g} \mathrm{mL}^{-1}\right.$ of malondialdehyde and $0.1-22 \mu \mathrm{g} \mathrm{mL}^{-1}$ of hexanal, respectively), it is obvious that these levels were lower in the current study. Of course, the oxidation conditions in both studies were different. An important difference which could be particularly relevant for malondialdehyde is that in the current study, the oil was oxidized prior to emulsification. We recently showed ${ }^{[18]}$ that the degradation of malondialdehyde in oil can be significant, especially at higher temperatures. In this respect, it is relevant to report that, in our study, upon oxidizing the fish oil at $60^{\circ} \mathrm{C}$ for a longer period than $6 \mathrm{~h}$, a drop in malondialdehyde concentration was observed (not shown). Thus, it seems that the degradation of malondialdehyde generated throughout lipid oxidation in an emulsified system could be further restricted. As for hexanal, further oxidation or evaporation cannot be excluded, as suggested earlier. ${ }^{[19]}$

A remarkable tendency is observed for the malondialdehyde content of emulsions, depending on the presence of Tween 20. For soybean oil-based emulsions, malondialdehyde concentrations were consistently higher in the presence of Tween 20 $(p<0.05)$. In contrast, an opposite trend was observed for fish oil-based emulsions $(p<0.05)$, except at the highest oxidation level evaluated, for which no significant differences could be detected. To understand these and other phenomena, a number of parallel phenomena should be considered as outlined below.

The first relevant mechanism to consider is the competitive displacement of adsorbed casein from interfaces in emulsions by Tween 20, as demonstrated by previous studies. ${ }^{[20-22]}$ Second, Tween 20 micelles in the aqueous phase could absorb lipid oxidation products. ${ }^{[23]}$ A third phenomenon that should be considered is the binding of Tween 20 to hydrophobic amino acids in proteins, making the interaction between malondialdehyde and proteins more diffcult to produce. ${ }^{[24,25]}$ The polarity of the oil is also likely to affect the Tween 20 adsorption at the interface. $^{[26-28]}$ Thus, the interface in emulsions containing more oxidized lipids stabilized by Tween 20 can be considered to be less compact and tightly packed than an interface solely composed of Tween 20. This phenomenon is suggested to increase the oxygen permeability of the interfacial membrane because of lower Tween 20 adsorption. As it has been shown in the current study that the lipid oxidation reaction proceeded at a significant rate during the preparation and subsequent short storage of the emulsion at cold temperatures, this aspect should also be considered.

Considering all of these phenomena, it is likely that in the case of soybean oil-based emulsions containing Tween 20, fewer protein molecules will be present at the interface, thus reducing the interaction between proteins and lipid oxidation products. As malondialdehyde is known to react irreversibly with proteins, its concentration in Tween 20 containing emulsions is expected to be higher, as was observed in our experiment. For the fish oilbased emulsions, however, this hypothesis cannot be corroborated. It could be hypothesized that for fish oil-based emulsions, the impact of newly generated malondialdehyde on the malondialdehyde levels observed during the ongoing oxidation process could be more important than previously assumed. Moreover, the presence of proteins at the emulsion interface is reported to favor oxidation reactions, ${ }^{[2]}$ which could potentially explain the higher levels of malondialdehyde found in caseinbased fish oil emulsions without Tween 20 . 
Table 4. Amino acid modification markers (Tryptophan, NFK and available lysine) in casein based emulsions containing stripped soybean oil or stripped fish oil at three levels of oxidation, stabilized or not by Tween 20 (After incubation $24 \mathrm{~h}$ at $4^{\circ} \mathrm{C}$ ).

\begin{tabular}{|c|c|c|c|c|c|c|c|c|c|}
\hline \multirow[b]{3}{*}{ Emulsions } & \multicolumn{9}{|c|}{ Oxidation level } \\
\hline & \multicolumn{3}{|c|}{ Tryptophan ( $\mu \mathrm{g} \mathrm{mg}^{-1}$ protein) } & \multicolumn{3}{|c|}{ NFK (Fluorescence) } & \multicolumn{3}{|c|}{ Lysine ( $\mathrm{mg} \mathrm{g}^{-1}$ protein) } \\
\hline & Low & Medium & High & Low & Medium & High & Low & Medium & High \\
\hline Casein containing soybean oil & $23.5 \pm 0.3^{\mathrm{a}}$ & $20.8 \pm 0.4^{b}$ & $17.3 \pm 0.1^{c}$ & $85.8 \pm 2.8^{\mathrm{a}}$ & $183.9 \pm 5.8^{b}$ & $157.4 \pm 5.4^{c}$ & $35.3 \pm 1.7^{\mathrm{a}}$ & $33.3 \pm 1.0^{\mathrm{a}}$ & $30.0 \pm 1.4^{b}$ \\
\hline Casein containing soybean oil and Tween 20 & $22.0 \pm 0.4^{\mathrm{a}}$ & $21.6 \pm 0.3^{a}$ & $20.3 \pm 0.1^{b}$ & $85.3 \pm 1.8^{\mathrm{a}}$ & $161.6 \pm 1.2^{b}$ & $123.2 \pm 1.6^{c}$ & $36.1 \pm 1.3^{a}$ & $36.7 \pm 0.7^{a}$ & $32.1 \pm 0.1^{b}$ \\
\hline Casein containing fish oil & $20.1 \pm 0.1^{\mathrm{a}}$ & $13.6 \pm 0.1^{b}$ & $16.8 \pm 0.1^{c}$ & $616.4 \pm 2.2^{\mathrm{a}}$ & $886.4 \pm 13.1^{b}$ & $905.8 \pm 14.5^{b}$ & $33.3 \pm 0.7^{\mathrm{a}}$ & $30.9 \pm 0.6^{b}$ & $33.0 \pm 1.4^{\mathrm{a}}$ \\
\hline Casein containing fish oil and Tween 20 & $19.8 \pm 0.2^{\mathrm{a}}$ & $17.5 \pm 0.4^{b}$ & $16.3 \pm 0.8^{c}$ & $598.7 \pm 19.7^{\mathrm{a}}$ & $822.1 \pm 10.9^{b}$ & $904.1 \pm 25.2^{c}$ & $35.2 \pm 0.7^{\mathrm{a}}$ & $32.0 \pm 1.0^{b}$ & $34.6 \pm 0.8^{\mathrm{a}}$ \\
\hline
\end{tabular}

Experimental data are presented as means of three independent replicates \pm standard deviation. Means with different superscript letters are significantly different $(p<0.05)$ in rows. Tryptophan and NFK in PBS pH 7.4.

With respect to the hexanal data, only emulsions containing soybean oil can be considered relevant in view of its low levels in fish oil-based emulsions. Soybean oil contains linoleic and linolenic acids that are precursors of hexanal, but this is not the case for fish oil, which contains comparatively more polyunsaturated fatty acids with two or more methylene interrupted double bonds (Table 1); consequently, more malondialdehyde is formed. As other authors have shown that the covalent modifications of proteins are quite restricted, the observed data could be explained by the impact of proteins in the interface on the lipid oxidation process. ${ }^{[29]}$ Slightly but significantly higher hexanal levels were observed in emulsions to which no Tween 20 was added $(p<0.05)$.

The presence of Tween 20 and its impact on the displacement of proteins at the interface, as well as its potential role in protecting proteins from reacting with lipid oxidation products, are confirmed by the data reported in Table 4 . The level of protein modification markers is consistently lower for emulsions containing Tween 20 for all oils at all oxidation levels evaluated, except for a fresh soybean oil-based emulsion with casein $(p<0.05)$, but for NFK, this trend could not be statistically supported. This is also the case for the losses of lysine. In addition, a normal trend was observed among generic protein modification markers as a function of oxidation level. This was not the case for NFK formation, which decreased in soybean-

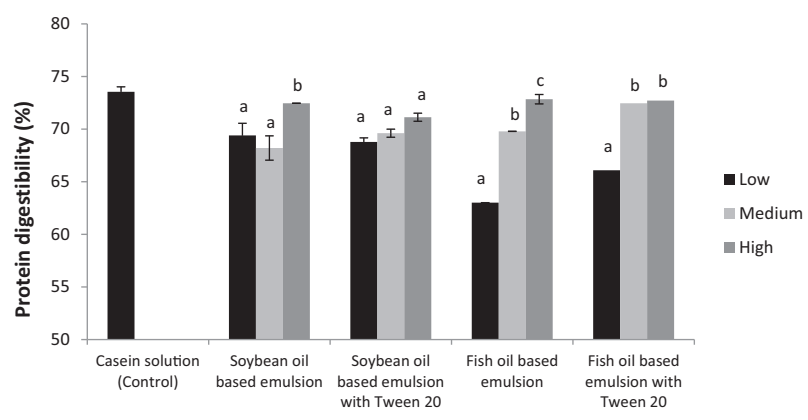

Figure 3. Protein digestibility (\%) in casein based emulsions containing stripped soybean oil or stripped fish oil at three levels of oxidation, stabilized or not by Tween 20 . Incubation $24 \mathrm{~h}$ at $4{ }^{\circ} \mathrm{C}$. The digestibility of casein solution (control without lipid) is $73.59 \% \pm 0.44$. based emulsions at the highest oxidation level evaluated. It is also notable that at the highest oxidation level of fish oil tested, the lysine content in the proteins was comparable to that in emulsions made from fish oil at the lowest oxidation level, although it should be mentioned that the fluctuations in lysine content were low. It could be hypothesized that as oil polarity increases, less and less protein is expected to be present at the interface. In the aqueous, phase, however, casein proteins can reassemble into micelles. ${ }^{[30,31]} \mathrm{k}$-casein covers the surface of micelles because it is the least hydrophobic casein compared to $\alpha$ - and $\beta$-caseins. ${ }^{[32]}$ In the case of caseinate, submicelles are formed because colloidal calcium phosphate is removed and sub-micelles, composed of a mixture of individual casein molecules, are formed in the aqueous phase. $\beta$-casein and $\kappa$-casein form spherical micelles in an aqueous solution. ${ }^{[33]} \kappa$-casein contains less tryptophan and lysine in the primary structure than $\alpha$ - and $\beta$ caseins, ${ }^{[34]}$ and, thus, it may protect the degradation of amino acids that are dominantly present inside the micelles. For the tryptophan data, again, a consistent drop in concentration was observed as a function of the degree of oxidation in the oils used.

With respect to the impact of co-oxidation on protein digestibility, this study showed quite surprising results considering our previously reported observations, ${ }^{[3]}$ in which we showed that the co-oxidation of proteins and lipids resulted in a significant drop in protein digestibility for a casein-based emulsion (down to only 44\% upon 30 days of light-induced oxidation at $4{ }^{\circ} \mathrm{C}$ ). In fact, the main effects are exerted by the oxidation level and emulsifier (Table 1), not by the type of oil. For soybean oil-based emulsions without Tween 20 that used the most oxidized oil, an impact on protein digestibility, which showed unexpected improvement, was observed. This observation was most consistent for fish oil-based emulsions, especially in the absence of Tween 20. Figures 5A and 5B, confirmed the results mentioned before. So, although we have shown in our previous research that the co-oxidation of proteins and lipids significantly affected protein digestibility, it seems that when oxidized lipids are emulsified in the presence of proteins, this impact was not observed and, on the contrary, better protein digestibility was obtained. This discrepancy suggests that apart from the impact of the interaction between lipid oxidation products and proteins, interfacial phenomena also play a role in the digestion of proteins in the models studied. These interfacial phenomena not only have an impact on the interactions of lipid 

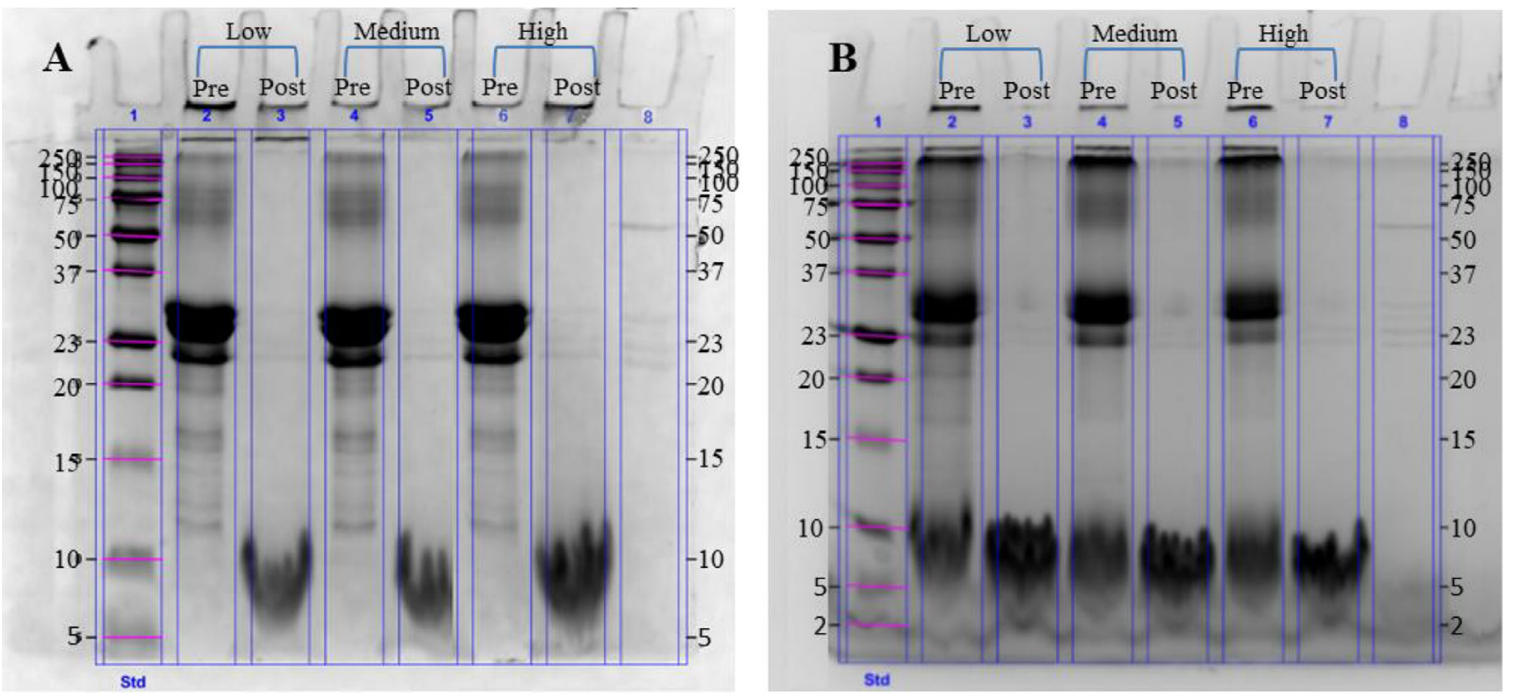

Figure 4. SDS-PAGE of casein based emulsions containing fish oil with different levels of oil oxidation stabilized or not by Tween 20 incubated for $24 \mathrm{~h}$ at $4{ }^{\circ} \mathrm{C}$. Samples pre and post in vitro gastrointestinal digestion. a) Casein based emulsions containing fish oil. b) Casein based emulsions containing fish oil stabilized by Tween 20. Lane 1: Standard Bio-Rad; lanes 2 and 3: emulsions containing low oxidized fish oil pre and post digestion, respectively; lanes 4 and 5: emulsions containing medium oxidized fish oil pre and post digestion, respectively; lanes 6 and 7: emulsions containing high oxidized fish oil pre and post digestion, respectively; lane 8: blank with phosphate buffer, digestive enzymes and bile salts.

oxidation products with proteins, as outlined above, but also have an impact on the accessibility of proteins for proteases. Indeed, introducing a polar oil to an emulsion will result in a changed interfacial composition.

By the addition of Tween 20 and due to the presence of oxidized lipid species at the interface, it can be supposed that the protein content at the interface is reduced. If Tween 20 is also present, the proteins are likely to be displaced even more completely, even if their protein digestibility is very close to the control (casein solution; $73.5 \pm 0.44 \%$ ). Figure 6 confirms the mentioned above, showing a complete digestion of casein solution compare to fish oil emulsions with oils with different oxidation level. This implies that the molecular changes in the proteins are induced due to a transfer of lipid oxidation products in the aqueous phase, which was confirmed by ${ }^{[18]}$ and is also in line with the markers for protein changes and lipid oxidation
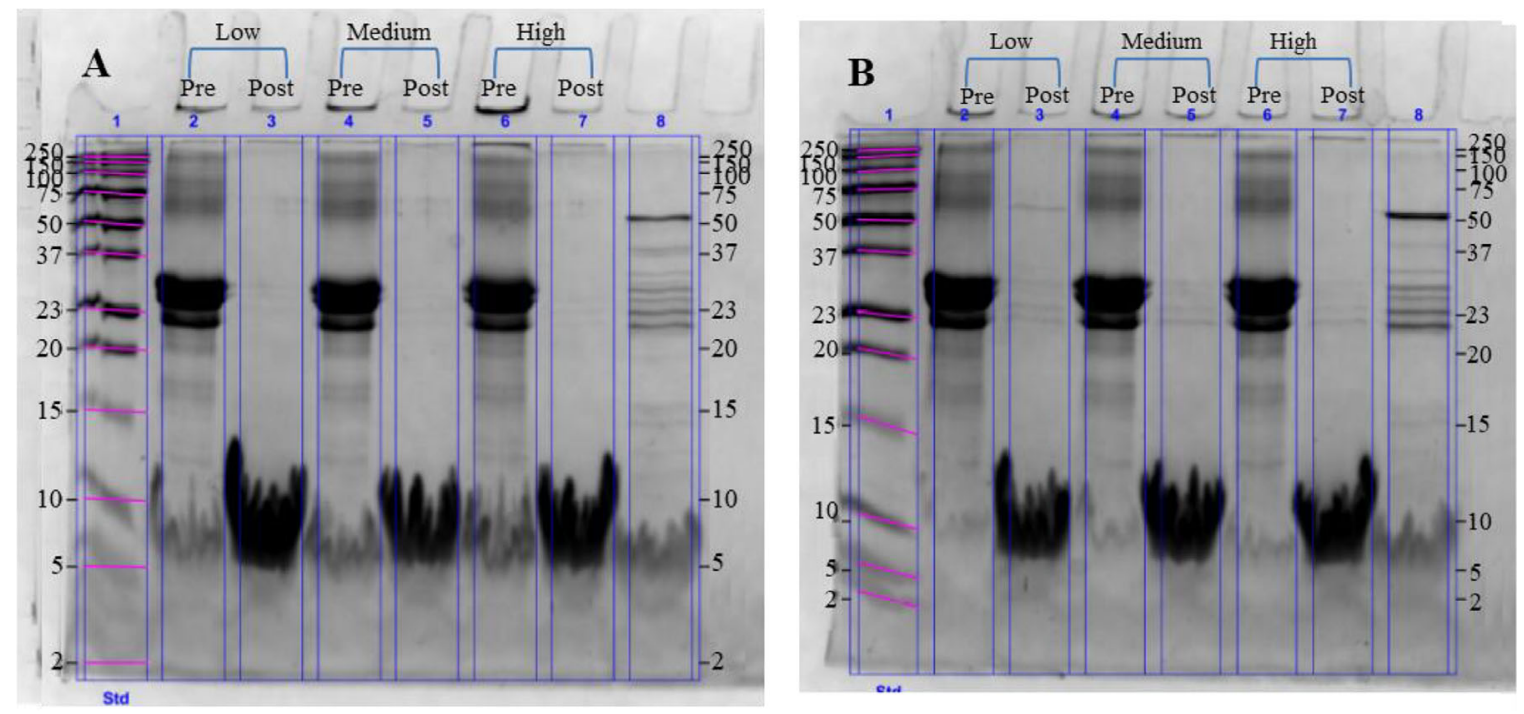

Figure 5. SDS-PAGE of casein based emulsions containing soybean oil with different levels of oil oxidation and stabilized or not by Tween 20 , incubated for $24 \mathrm{~h}$ at $4{ }^{\circ} \mathrm{C}$. Samples pre and post in vitro gastrointestinal digestion. a) Casein based emulsions containing soybean oil. b) Casein based emulsions containing soybean oil stabilized by Tween 20. Lane 1: Standard Bio-Rad; lanes 2 and 3: emulsions containing low oxidized soybean oil pre and after post digestion, respectively; lanes 4 and 5: emulsions containing medium oxidized soybean oil pre and post digestion, respectively; lanes 6 and 7: emulsions containing high oxidized soybean oil pre and post digestion, respectively; lane 8: blank with phosphate buffer, digestive enzymes and bile salts. 


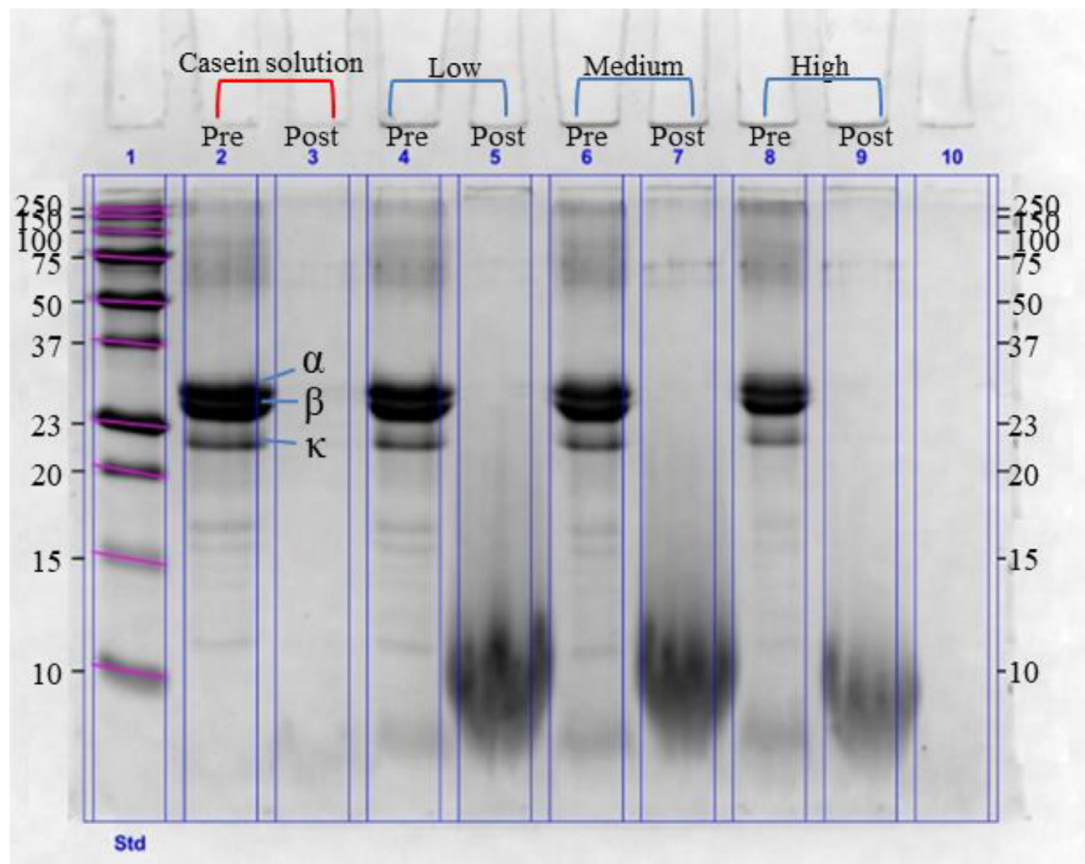

Figure 6. SDS-PAGE of casein solution (control without lipid) and fish oil based emulsion with different oxidation level, incubated for $24 \mathrm{~h}$ at $4{ }^{\circ} \mathrm{C}$. Samples pre and post in vitro gastrointestinal digestion. Lane 1: Standard Bio-Rad; lane 2 and 3: casein solution pre and post digestion, respectively; lane 4 and 5: emulsions containing low oxidized fish oil pre and post digestion, respectively; lane 6 and 7: emulsions containing medium oxidized fish oil pre and post digestion, respectively; lane 8 and 9: emulsions containing high oxidized fish oil pre and post digestion, respectively; lane 10: phosphate buffer.

products reported earlier in this study. However, the impact of these molecular changes - that is, the changes in proteins that are present in the aqueous phase - on protein digestibility seems to remain restricted.

Thus, there are two opposite effects of lipid oxidation on protein digestibility in the studied emulsions. On the one hand, a higher degree of oxidation in the oil used will affect the protein as well as its digestibility, but on the other hand, if multiple polar lipids are present, the adsorption of proteins at the interface will be restricted because of the decreased hydrophobic effect. These conflicting effects could also explain the differences observed in protein digestibility for fish oil- and soybean oil-based emulsions at the lowest oxidation level studied.

\section{Conclusion}

The present study demonstrated that oxidizing lipids have a particular impact on proteins if both proteins and oils are emulsified together and are subsequently subjected to an oxidation process. This scenario is, obviously, the most relevant for real foods. The potential mechanisms behind this phenomenon are likely to be a combination of protein modifications and restricted protein availability because modified proteins are attached to the interface. If proteins are emulsified in the presence of oxidized lipids, the results can differ because the interface is not yet formed, and the composition of the interface 88, 603. will depend upon the degree of oil oxidation (as well as the presence of other amphiphilic compounds). If the oil is more oxidized, fewer proteins will be present at the interface, restricting the impact of lipid oxidation products on proteins.

\begin{abstract}
Abbreviations
ANOVA, analysis of variance; AOAC, association of analytical chemists; BHA, butilated hydroxyanisol; DNPH, 2,4-dinitrophenylhydrazine; HS-SPME, headspace solid-phase microextraction; MDA, malondialdehyde; NFK, N-Formylkynurenine; OPA, Orthophtalaldehyde; SDS-PAGE, sodium dodecyl sulphate polyacrylamide gel electrophoresis; TBA, 2-thiobarbituric acid; TCA, trichloroacetic acid; TEP, 1,1,3,3tetraethoxypropane.
\end{abstract}

\section{Acknowledgments}

Thanks to VLIR-OUS (Belgium) and University of Tolima (Colombia) for supporting this research.

\section{Conflict of Interest}

The authors declare no conflict of interest.

\section{Keywords}

casein, emulsion, lipid oxidation, protein digestibility, Tween 20

Received: July 27,2017

Revised: January 24, 2018 Published online:

[1] K. Schaich, A. Kamal-Eldin, D. B. Min, (Eds.), Co-oxidation of Proteins by Oxidizing Lipids in Lipid Oxidation Pathways, Vol. 2, AOCS Press, United States of America 2008, pp. 181-272.

[2] C. Berton, M.-H. Ropers, D. Guibert, V. Sole, C. Genot, J. Agric. Food Chem. 2012, 60, 8659.

[3] M. Obando, A. Papastergiadis, S. Li, B. De Meulenaer, J. Agric. Food Chem. 2015, 63, 9820.

[4] S. Y. Zhou, E. A. Decker, J. Agric. Food Chem. 1999, 47, 1932.

[5] H. H. F. Refsgaard, L. Tsai, E. R. Stadtman, P. Natl. Acad. Sci. USA. 2000, 97, 611 .

[6] F. Mestdagh, B. Kerkaert, T. Cucu, B. De Meulenaer, Food Chem. 2011, 126, 1190.

[7] C. C. Berton-Carabin, M. Ropers, C. Genot, Compr. Rev. Food Sci. F. 2014, 13, 945.

[8] E. Goicoechea, E. F. A. Brandon, M. H. Blokland, M. D. Guillen, Food Chem. Toxicol. 2011, 49, 115.

[9] B. Kerkaert, F. Mestdagh, T. Cucu, K. Shrestha, J. Van Camps, B. De Meulenaer, Amino Acids 2012, 43, 951.

[10] A. Mariod, B. Matthaeus, I. H. Hussein, J. Am. Oil Chem. Soc. 2011,

[11] N. C. Shantha, E. A. Decker, Rapid, sensitive, iron-based spectrophotometric methods for determination of peroxide values of food lipids. J. AOAC Int. 1994, 77, 421. 
[12] AOCS. Official Methods and Recommended Practices, 5th Ed. Cd 1890 AOAC International, Champaign, IL 1998.

[13] F. Mestdagh, B. Kerkaert, T. Cucu, B. De Meulenaer, Food Chem. 2011, 126, 1190.

[14] A. Papastergiadis, E. Mubiru, H. Van Langenhove, B. De Meulenaer, J. Agric. Food Chem. 2012, 60, 9589.

[15] C. L. Hawkins, M. J. Davies, Biochem. J. 1998, 332, 617.

[16] T. K. Dalsgaard, D. Otzen, J. H. Nielsen, L. B. Larsen, J. Agric. Food Chem. 2007, 55, 10968.

[17] E. Ferrer, A. Alegria, R. Farre, P. Abellan, F. Romero, G. Clemente, J. Sci. Food Agr. 2003, 83, 465.

[18] A. Vandemoortele, B. De Meulenaer, J. Agric. Food Chem. 2015, 63, 5694.

[19] F. Mestdagh, B. De Meulenaer, J. De Clippeleer, F. Devlieghere, A. Huyghebaert, J. Dairy Sci. 2005, 88, 499.

[20] J. L. Courthaudon, E. Dickinson, Y. Matsumura, D. C. Clark, Colloid Surface 1991, 56, 293.

[21] E. Dickinson, Colloid Surface B. 1999, 15, 161.

[22] A. R. Mackie, A. P. Gunning, P. J. Wilde, V. J. Morris, Langmuir 2000 16, 2242.

[23] C. Nuchi, P. Hernandez, D. J. McClements, E. Decker, J. Agric. Food Chem. 2002, 50, 5445.
[24] M. Coke, P. J. Wilde, E. J. Russell, D. C. Clark, J. Colloid Interf. 1990, 138,489

[25] M. A. Bos, T. van Vliet, Adv. Colloid Interfac. 2001, 91, 437.

[26] E. A. Decker, J. Alamed, I. A. Castro, J. Am. Oil Chem. Soc. 2010, 87, 771.

[27] K. Kittipongpittaya, B. Chen, A. Panya, D. J. McClements, E. A. Decker, J. Am. Oil Chem. Soc. 2012, 89, 2187.

[28] M. Mosca, F. Cuomo, F. Lopez, A. Ceglie, Food Res. Int. 2013, 50, 377.

[29] A. Meynier, V. Rampon, M. Dalgalarrondo, C. Genot, Int. Dairy J. 2004, 14, 681.

[30] M. Vinceković, M. Curlin, D. Juraš, J. Agric. Food Chem. 2014, 62, 8543.

[31] C. Broyard, F. Gucheron, Dairy Sci. Technol. 2015, 95, 437.

[32] P. Walstra, J. Wouters, T. Geurts, Milk Components in Dairy Science and Technology, 2nd ed. Taylor \& Francis CRC Press, Boca Raton, USA 2006, pp. 63-83.

[33] M. Panoville, L. Benyahia, D. Durand, T. Nicolai, J. Colloid Interface Sci. 2005, 287, 468.

[34] H. E. Swaisgood, Chemistry of the caseins in Advanced Dairy Chemistry, Vol. 1, (Eds: P. F. Fox, P. L. H. McSweeney), 3rd ed., part A Kluwer Academic/Plenum, New York, USA 2003, pp. 154-185. 